\title{
Gomisin N isolated from Schisandra chinensis significantly induces anti-proliferative and pro-apoptotic effects in hepatic carcinoma
}

\author{
SU YOUN YIM ${ }^{1 *}$, YOU JIN LEE ${ }^{2 *}$, YOEN KYUNG LEE ${ }^{3}$, SEUNG EUN JUNG ${ }^{3}$, \\ JI HA KIM ${ }^{3}$, JI EUN KIM ${ }^{3}$, HAK JIN KIM ${ }^{4}$, BEUNG GU SON ${ }^{2}$, YOUNG HOON PARK ${ }^{2}$, \\ YOUNG GUEN LEE ${ }^{5}$, YOUNG WHAN $\mathrm{CHOI}^{2}$ and DAE YOUN HWANG ${ }^{3}$
}

\begin{abstract}
${ }^{1}$ Department of Laboratory Animal Resources, National Institute of Toxicological Research, Korean FDA, Seoul 122-704; Departments of ${ }^{2}$ Horticultural Bioscience, ${ }^{3}$ Biomaterial Science, ${ }^{4}$ Bio-Industrial Machinery Engineering, and ${ }^{5}$ Food Science and Technology, College of Natural Resources and Life Science, Pusan National University/ PNU-Laboratory Animal Resource Center, Miryang-si, Gyeongsangnam-do 627-706, Korea
\end{abstract}

Received April 27, 2009; Accepted June 11, 2009

DOI: $10.3892 / \mathrm{mmr} 00000163$

\begin{abstract}
Lignans isolated from Schisandria chinensis have been prescribed as anti-cancer and anti-hepatitis treatments in Chinese medicine. To investigate the applications of lignans isolated from Schisandria chinensis in hepatic carcinoma therapy, their apoptotic ability was screened using a cell proliferation assay. Compared to the other lignans, gomisin $\mathrm{N}$ induced high apoptotic levels in hepatic carcinoma. Cell morphology and flow cytometric analysis demonstrated that this lignan induced cell death at high concentrations, but did not induce any changes at low concentrations. In addition, the expression levels of Bcl-2 and Bax proteins, which are involved in the apoptotic pathway, were markedly increased in only the $320 \mu \mathrm{M}$-treated group compared to the vehicle and other concentration groups, while the expression level of p53 protein remained unchanged in this group. These results suggest that gomisin $\mathrm{N}$ is an anti-cancer drug candidate capable of inhibiting the proliferation and inducing the apoptosis of human hepatic carcinomas.
\end{abstract}

Correspondence to: Professor Dae Youn Hwang, Department of Biomaterial Science, College of Natural Resources and Life Science, Pusan National University, 50 Cheonghak-ri, Samnangjin-eup, Miryang-si, Gyeongsangnam-do 627-706, Korea

E-mail: dyhwang@pusan.ac.kr

Professor Young Whan Choi, Department of Horticultural Bioscience, College of Natural Resources and Life Science, Pusan National University, 50 Cheonghak-ri, Samnangjin-eup, Miryang-si, Gyeongsangnam-do 627-706, Korea

E-mail: ywchoi@pusan.ac.kr

${ }^{*}$ Contributed equally

Key words: gomisin N, anti-proliferation, apoptosis, Bcl-2, Bax

\section{Introduction}

Schisandra chinensis has a well-recognized history in traditional Chinese medicine. 'Chinese Magnolia', as it is commonly called, is widely distributed in the eastern regions of Siberia, China, Japan and Korea (1). Over the past 20 years, many active lignans have been isolated from this plant, including gomisin A, B, C, D, E, F, G, K3, N, J, schisandrol B, schisandrin and schisandrin $\mathrm{C},(1,2)$.

Based on their therapeutic properties, these lignans have been classified into four major categories: adaptogenic action, hepatic protection, hepatic stabilization and hepatic regeneration. The first category, adaptogenic action, has specific action mechanisms, with lignans acting as energizers, stimulaters of the nervous system, oxygenators, immune-modulators, antioxidants and skin protectors (1,3-6). These lignans have also been found to reduce hyperlipidemia and to significantly inhibit the development of arteriosclerosis (7). The second category is hepatic protection. These lignans have been closely correlated with increases in the hepatic level of ascorbic acid, the inhibition of NADPH oxidization and lipid peroxydization, and the induction effect of the hepatic microsomal cytochrome P-450 enzyme. Hepatic protection lignans have also been reported to protect against cholestasis induced by toxic substances (8-11). Regarding the third category, hepatic stabilization, previous studies have shown that these compounds contribute to the hepatic regeneration process through the induction of hepatocyte growth factor mRNA transcription, the stimulation of hepatocyte proliferation, and increased blood flow to the liver. In addition, in order to improve regenerative capacity through reduced glutation and the synthesis of hepatic glucogen, these lignans induce an increase in the levels of mitochondrial hepatic glutation and the activity of mitochondrial reductase glutation $(12,13)$. However, few functional studies have been conducted to fully investigate whether the lignans isolated from Schisandra chinensis have an effect on cell death in hepatic carcinoma in vitro. 
The present study investigated the functions involved in the anti-cancer effects of several compounds isolated from Schisandra chinensis. Four lignans were screened using the MTT assay. Of these lignans, gomisin N significantly induced cell death in hepatic carcinoma. These results suggest that gomisin $\mathrm{N}$ has anti-cancer effects in hepatic carcinoma.

\section{Materials and methods}

Reagents. Minimum essential medium (MEM) powder, trypsin and antibiotics (100 U/ml penicillin and $100 \mu \mathrm{g} / \mathrm{ml}$ streptomycin) were purchased from Gibco (Grand Island, NY, USA). Fetal bovine serum (FBS) was supplied by Invitrogen (NY, USA). All other chemicals were purchased from SigmaAldrich (St. Louis, MO, USA).

Plant material. The fruits of Schisandra chinensis used in this study were collected from Moonkyeng-city in Korea in September of 2005. A voucher specimen (accession no. SC-PNUNPRL-1) was deposited in the Herbarium of Pusan National University.

Extraction and structure elucidation of the compound. The dried fruits of Schisandra chinensis $(2.5 \mathrm{~kg})$ were ground to a fine powder and successively extracted at room temperature with $n$-hexane, EtOAc and MeOH. The hexane extract (308 g) was evaporated under a vacuum and chromatographed on a silica gel (40 $\mu \mathrm{m}$; J.T. Baker, NJ, USA) column $(70$ x $8.0 \mathrm{~cm})$ with a step gradient of 0, 5, 10, 20 and 30\% EtOAc in hexane (1 liter each) (14). Of these extracts, fraction 11 (3,476 mg) was separated on a silica gel column $(100 \times 3.0 \mathrm{~cm})$ with $25 \%$ hexane in $\mathrm{CHCl}_{3}$ to generate 5 fractions. Fraction 11IA, one of the five subfractions originating from fraction 11, was further purified by column chromatography on silical gel and eluted with $\mathrm{CHCl}_{3}$-acetone (19:1) to produce gomisin $\mathrm{N}$ (774 mg). Fraction $8(1,579 \mathrm{mg})$ was separated on a silica gel column $(100 \times 3.0 \mathrm{~cm})$ with $\mathrm{CH}_{2} \mathrm{Cl}_{2}$ to produce schisandrin $\mathrm{C}(501 \mathrm{mg})$. Fraction $29(1,992 \mathrm{mg})$ was separated on a silica gel column $(100 \times 3.0 \mathrm{~cm})$ with $15 \% \mathrm{CHCl}_{3}$ in acetone to produce gomisin A (973 mg). Fractions 36, 37 and $38(10,533 \mathrm{mg})$ were separated on a silica gel column $(100 \times 3.0 \mathrm{~cm})$ with $5 \% \mathrm{CH}_{2} \mathrm{Cl}_{2}$ in acetone to produce schisandrin $(4,606 \mathrm{mg})$.

Pure gomisin A was identified by high performance liquid chromatography on a Phenomenex Luna C18 column (Phenomenex; 150 x 4.6 mm I.D., 5- $\mu$ m particle size) (15). The chemical structure of all lignans used in this study was verified by liquid chromatography-mass spectrometry (LC-MS; Bruker BioApex FT Mass Spectrometer) and nuclear magnetic resonance (NMR) analysis (Varian Inova 500 Spectrometer). Optical rotations were recorded on a Jasco DIP-370 Digital Polarimeter. IR spectra were recorded on an AATI Mattson Genesis Series FTIR. NMR spectra $\left({ }^{1} \mathrm{H},{ }^{13} \mathrm{C}\right)$ were recorded in $\mathrm{CDCl}_{3}$ on a Varian Inova 500 Spectrometer operating at 500 $\mathrm{MHz}$ for ${ }^{1} \mathrm{H}$ and $125 \mathrm{MHz}$ for ${ }^{13} \mathrm{C}$, running gradients and using residual solvent peaks as internal references. High-resolution mass spectra were recorded on a Bruker BioApex FT Mass Spectrometer.

Cell culture and treatment. HepG2, a human hepatoblastoma cell line, was purchased from the Korean Cell Line Bank
(Seoul, Korea). This cell line was grown in monolayers in MEM supplemented with $10 \%$ FBS and antibiotics $(100 \mathrm{U} / \mathrm{ml}$ penicillin and $100 \mu \mathrm{g} / \mathrm{ml}$ streptomycin), incubated at $37^{\circ} \mathrm{C}$ in a humidified incubator containing $5 \% \mathrm{CO}_{2}$ in air.

Cell proliferation assay. First, the wells of a 96-well plate were divided into four groups in preparation for gomisin $\mathrm{N}$, schisandrin, schisandrin $\mathrm{C}$ and gomisin A treatment. These groups were further classified into 5 subgroups of different concentrations (vehicle, 40, 80, 160 and $320 \mu \mathrm{M}$ ). HepG2 cells were seeded at a density of $4 \times 10^{4}$ cells $/ 200 \mu \mathrm{l}$ in a 96 -well plate and grown for $24 \mathrm{~h}$ in an incubator at $37^{\circ} \mathrm{C}$. When the cells attained $70-80 \%$ confluence, various concentrations of gomisin $\mathrm{N}$ dissolved in dimethyl sulfoxide (DMSO) were added to each well and the cells were further incubated for another $24 \mathrm{~h}$. Cell proliferation was evaluated using the tetrazolium compound MTT [3-(4,5-dimethylthiazol-2-yl)-2,5-diphenyltetrazolium bromide, Sigma M2128). After the supernatant in the lignanand vehicle-treated wells was discarded, $200 \mu \mathrm{l}$ of fresh MEM solution and $50 \mu \mathrm{l}$ of MTT solution ( $2 \mathrm{mg} / \mathrm{ml}$ in PBS) were added to each well. These cells were then incubated in an incubator at $37^{\circ} \mathrm{C}$. MTT is reduced by metabolically active cells to insoluble purple formazan dye crystals. After $4 \mathrm{~h}, 220 \mu \mathrm{l}$ of the MTT mixture was removed from each well, and MTT formazan precipitates were dissolved in $150 \mu \mathrm{l}$ of DMSO. Finally, the absorbance of the sample in the well was directly read using a SoftMax Pro5 Spectrophotometer (Molecular Devices, USA). The optimal absorbance wavelength was set at $570 \mathrm{~nm}$. Data involving cell number versus absorbance were analyzed, allowing for the quantification of changes in cell proliferation.

Flow cytometric analysis. The percentage of cells undergoing apoptosis and dead cells were detected using FITC Annexin V staining (BD Bioscience, USA). HepG2 cells were seeded at a density of $2 \times 10^{6}$ cells in $100-\mathrm{mm}^{2}$ dishes and grown for $24-48 \mathrm{~h}$ in an incubator at $37^{\circ} \mathrm{C}$. When the cells attained $70-80 \%$ confluence, various concentrations of gomisin $\mathrm{N}$ solution were added to each culture dish, and the cells were further incubated for an additional $24 \mathrm{~h}$. Each group of cells was harvested, washed twice with ice-cold PBS, and then resuspended in $1 \mathrm{X}$ binding buffer at a concentration of $1 \times 10^{6}$ cells $/ \mathrm{ml}$. Subsequently, $\sim 1 \times 10^{5}$ cells in $100 \mu \mathrm{l}$ of solution were transferred to a round-bottom culture tube. FITC Annexin V $(5 \mu \mathrm{l})$ was added to stain the cells. After a 15-min incubation at room temperature, $400 \mu \mathrm{l}$ of $1 \mathrm{X}$ binding buffer was added to each tube, and the cells were analyzed by FACSCalibur (BD Biosciences) within $1 \mathrm{~h}$.

Western blot analyses. The HepG2 cells harvested from the $100-\mathrm{mm}^{2}$ culture dish were solubilized with $1 \%$ Nonidet $\mathrm{P}-40$ in $150 \mathrm{mM} \mathrm{NaCl}, 10 \mathrm{mM}$ Tris $\mathrm{HCl}(\mathrm{pH} \mathrm{7.5)}$ and $1 \mathrm{mM}$ EDTA, and supplemented with a protein inhibitor mixture (Roche, Germany). They were then centrifuged at 10,000 x g for $10 \mathrm{~min}$ at $4^{\circ} \mathrm{C}$. The homogenated proteins were separated on $10 \%$ sodium dodecyl sulfate polyacrylamide gels for $3 \mathrm{~h}$ and transferred to nitrocellulose membranes over $2 \mathrm{~h}$ at $40 \mathrm{~V}$. The membranes were then incubated with primary antibodies [anti-Bcl-2 (SC-7382), anti-Bax (SC-493), anti-p53 (SC-6243) and anti- $\alpha$-tubulin (Sigma)] to detect Bcl-2, Bax, p53 and 
A.<smiles>COc1cc(C)cc(C(C)(C)C(C)(C)C)c1OC</smiles>

C.

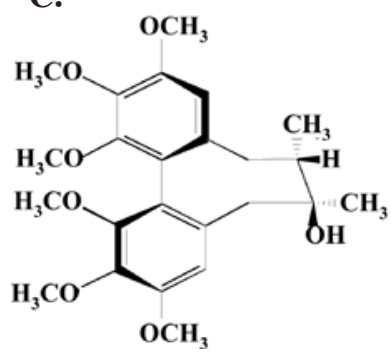

B.<smiles>COc1cc(C)cc(C(C)(C)C)c1C(C)(C)C</smiles>

D.

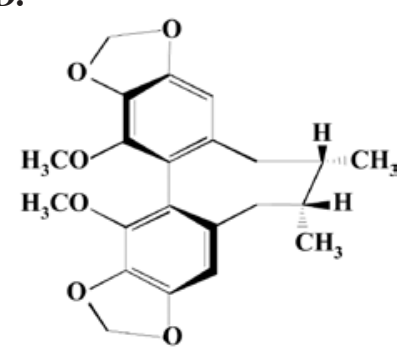

Figure 1. Chemical structure of four lignans isolated from Schisandra chinensis: (A) gomisin N, (B) gomisin A, (C) schisandrin and (D) schisandrin C.

anti- $\alpha$-tubulin. Each antigen-antibody complex was visualized with a biotinylated secondary antibody, (goat anti-rabbit)conjugated HRP streptavidin (Zymed, Histostain-Plus Kit), diluted 1:1,500 in $1 \mathrm{X}$ PBS.

Statistical analysis. Tests for the significance between vehicletreated and compound-treated groups were performed using a one-way ANOVA test of variance (SPSS for Windows, release 10.10, standard version, Chicago, IL, USA). All values were reported as the mean \pm standard deviation (SD). P-values $<0.05$ were considered significant.

\section{Results}

Isolation of four lignans from Schisandra chinensis. In order to prepare lignans for the study of their anti-cancer effects, various compounds were extracted from Schisandra chinensis by $n$-hexane, EtOAc and MeOH. Subsequently, four lignans that were extracted in large quantities compared to the other lignans were harvested. The structure of these lignans was determined by LC-MS and NMR analysis, and the lignans were identified as gomisin N (16), schisandrin (17), schisandrin C (16) and gomisin A $(18,19)$ (Fig. 1). Chromatography verified that the four lignans were pure enough to be used in experiments to determine their anti-cancer effects (Fig. 2). Thus, four lignans for testing anti-cancer effects were successfully isolated from Schisandra chinensis and used for further experimentation.

Effects of the four extracts on cell proliferation. To select the lignan with the highest apoptotic effect on hepatic carcinomas, the MTT assay was used to screen proliferation activity in each group receiving one of the four lignans at varying concentrations. Schisandrin $\mathrm{C}$ was found to induce cell proliferation rather than cell death in HepG2 cells at concentrations

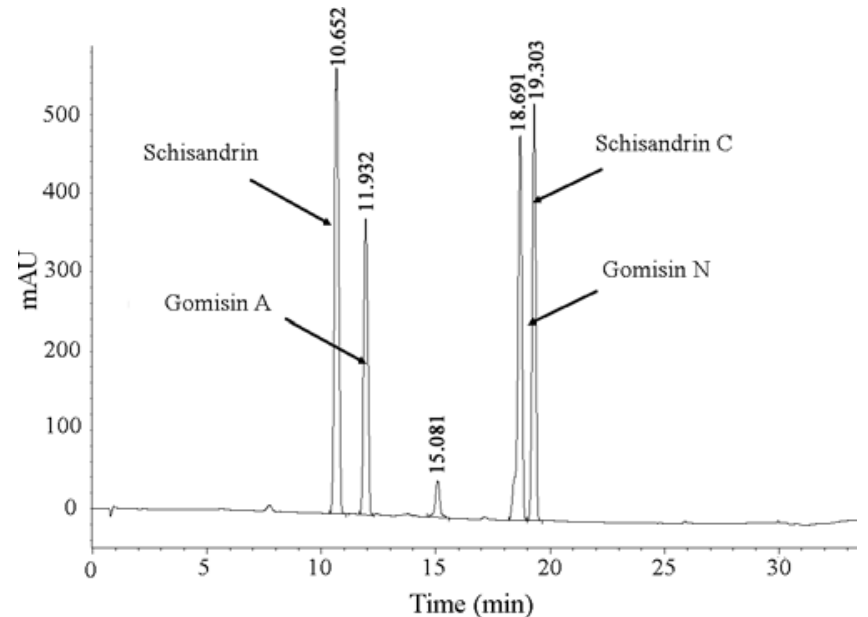

Figure 2. High performance liquid chromatography (HPLC) profiles of the lignans of Schisandra chinensis: gomisin N, gomisin A, schisandrin and schisandrin C. HPLC analysis showed that the isolated lignans were $>96 \%$ pure.

of $40-160 \mu \mathrm{M}$ (Fig. 3D). Cell proliferation in the gomisin A-treated group remained at a constant level (Fig. 3B). However, two lignans, gomisin $\mathrm{N}$ and schisandrin, significantly induced cell death in comparison to the other lignans. Cell proliferation in the $40 \mu \mathrm{M}$ gomisin-treated group was slightly increased compare to the vehicle, while cell proliferation rapidly decreased with concentrations of gomisin $\mathrm{N}$ ranging from 80 to $320 \mu \mathrm{M}$ (Fig. 3A). Schisandrin also induced cell death at higher concentrations, but with a lower cell death ratio than gomisin N (Fig. 3C). These results indicate that gomisin N treatment was highly effective in inducing the death of HepG2 cells at high concentrations, but not at low concentrations. Gomisin $\mathrm{N}$ was therefore selected for further analysis as the most suitable candidate lignan, with proven anti-proliferation and pro-apoptosis activity.

Effects of gomisin $N$ on cell morphology. In order to study whether the cell death effects observed using the MTT assay were concurrent with cell morphological changes, HepG2 cells were observed using a phase-contrast microscope after $24 \mathrm{~h}$ of treatment with various concentrations of gomisin $\mathrm{N}$. In the $40 \mu \mathrm{M}$-treated group, the number and morphology of HepG2 cells were increased compared to the vehicle-treated group. HepG2 cells in the $80 \mu \mathrm{M}$-treated groups showed a pattern similar to the vehicle-treated group, while in the $160 \mu \mathrm{M}$-treated group a small number of dead cells was observed. In the groups treated with $320 \mu \mathrm{M}$, the number of cells was markedly increased (Fig. 4). Thus, the results of cell morphology analysis of gomisin N-treated cells corroborated the results of the MTT assay.

Effects of gomisin $\mathrm{N}$ on apoptosis. FITC Annexin V is used to quantitatively determine the percentage of cells within a population that are actively undergoing apoptosis (20,21). To investigate the effect of gomisin $\mathrm{N}$ on apoptosis, HepG2 cells treated with various concentrations of gomisin $\mathrm{N}$ were stained with FITC Annexin V, and fluorescence was detected by flow cytometry. As shown in Fig. 5, gomisin N significantly induced a $15-98 \%$ increase in the number of cells undergoing 

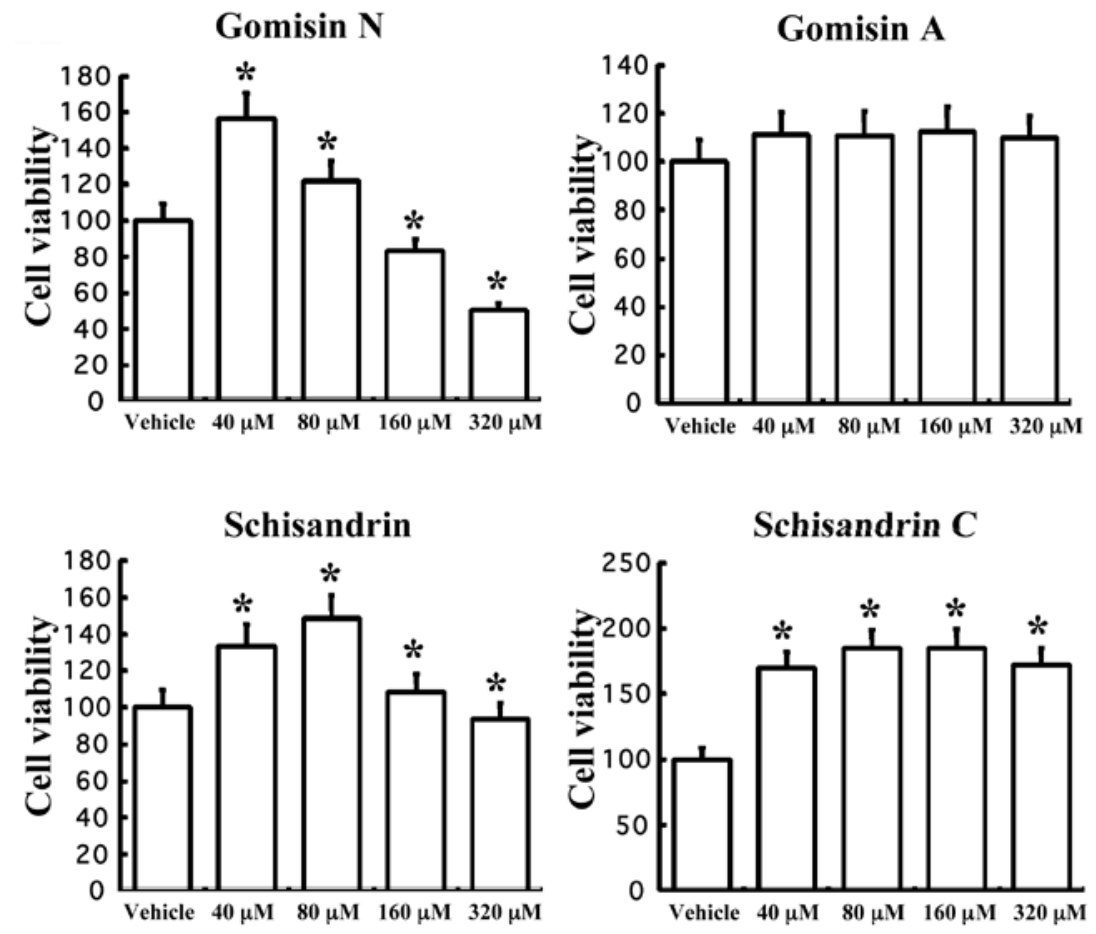

Figure 3. Anti-proliferative effect of the four Schisandra chinensis compounds on the HepG2 cell line. Cells were cultured with one of the four compounds in DMSO at various concentrations for $24 \mathrm{~h}$. The vehicle was treated with DMSO only. Cell proliferation was measured using the MTT assay. Data represent as the mean $\pm \mathrm{SD}$ of three experiments. ${ }^{*} \mathrm{P}<0.05$ compared to the vehicle-treated group, set as the level of significance.
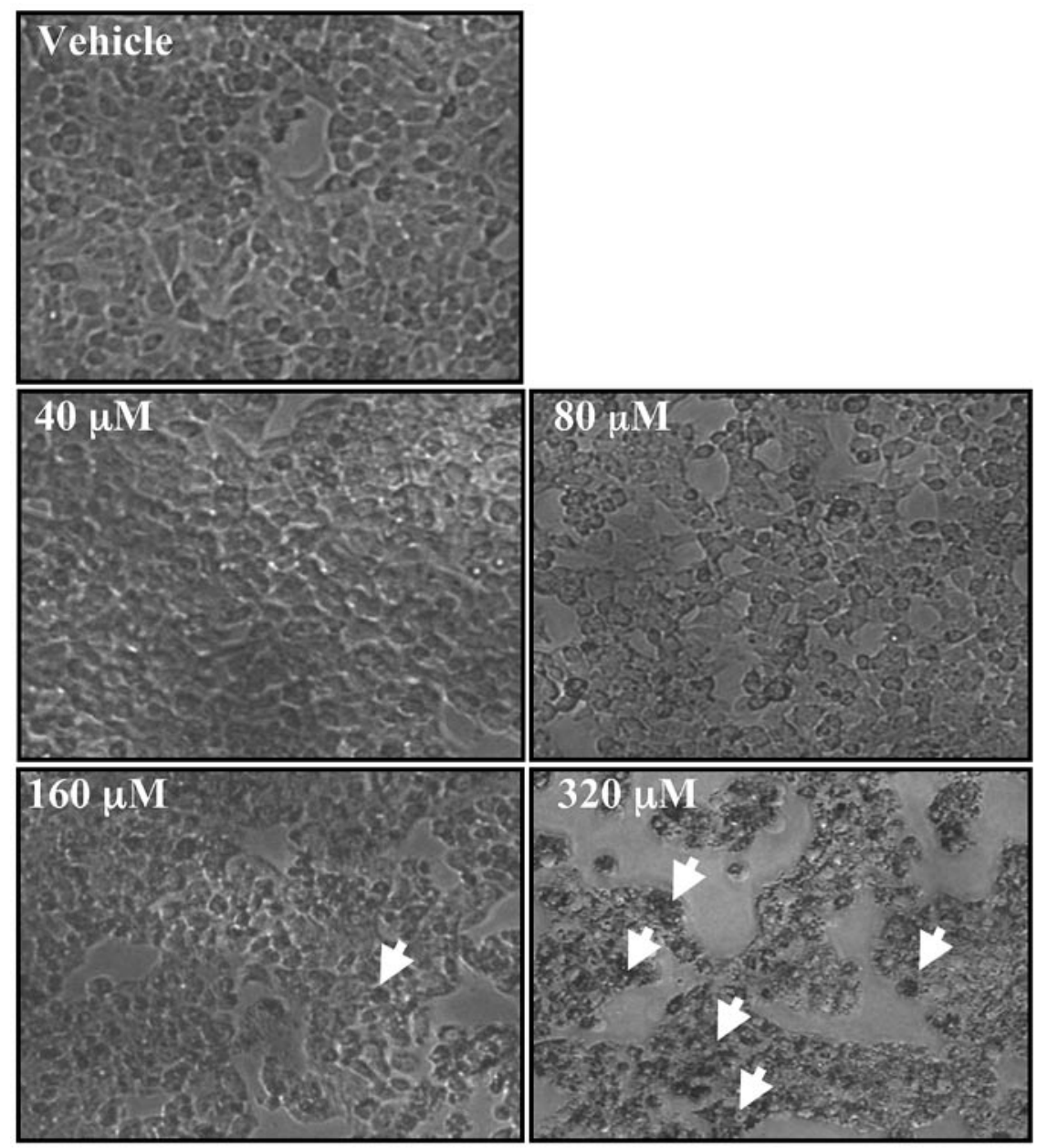

Figure 4. Microscopic images of HepG2 cells after $24 \mathrm{~h}$ of treatment with gomisin N at various concentrations. Vehicle-treated cells were treated with DMSO using the dissolving agents of the four Schisandra chinensis compounds. Cellular morphology was viewed at x20 magnification. 

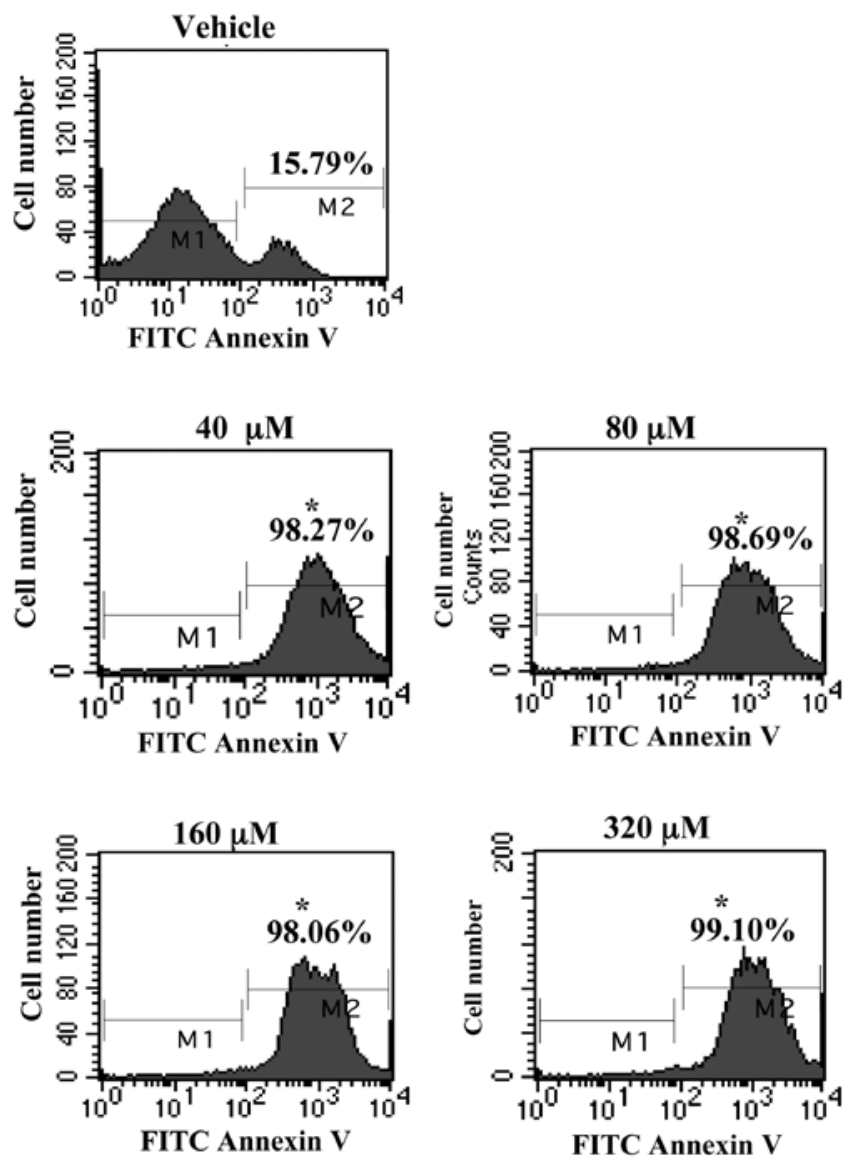

Figure 5. Identification of apoptotic cells. HepG2 cells were incubated with gomisin $\mathrm{N}$ at various concentrations for $24 \mathrm{~h}$ and stained with FITC Annexin $\mathrm{V}$ in order to detect apoptotic cells. The fluoresence emitted by these cells was analyzed using a flow cytometer. M1 indicates live cells; M2, cells undergoing apoptosis or cells that had already died. Data represent the mean $\pm \mathrm{SD}$ of three experiments. ${ }^{*} \mathrm{P}<0.05$ compared to the vehicle-treated group, set as the level of significance.

apoptosis at $24 \mathrm{~h}$. However, this reaction was induced at even low concentrations of gomisin $\mathrm{N}$, and the level of induction remained at a constant level for higher concentrations. These results suggest that gomisin $\mathrm{N}$ dose-independently induces the apoptosis of HepG2 cells. Specifically, gomisin N induced the loss of plasma membrane asymmetry, one of the early events in the apoptotic process, for most of the cells treated at a concentration of $40 \mu \mathrm{M}$.

Effects of gomisin $N$ on the apoptic pathway. Bcl-2 belongs to a family of proteins that includes both pro- and anti-apoptotic members. Of these members, Bcl-2 protein stimulates the anti-apoptotic process, while Bax protein significantly inhibits its anti-apoptotic actions $(22,23)$. In order to study the effects of gomisin $\mathrm{N}$ treatment on the proteins associated with the apoptotic signaling pathway, the expression levels of Bcl-2 and Bax were determined in the vehicle- and gomisin N-treated groups using Western blot analysis. The expression level of Bcl-2 protein did not change in the low concentration range compared to the vehicle. However, the high concentration 160 and $320 \mu \mathrm{M}$-treated groups showed a higher expression level of Bcl-2 protein than the groups in the low concentra-
A.

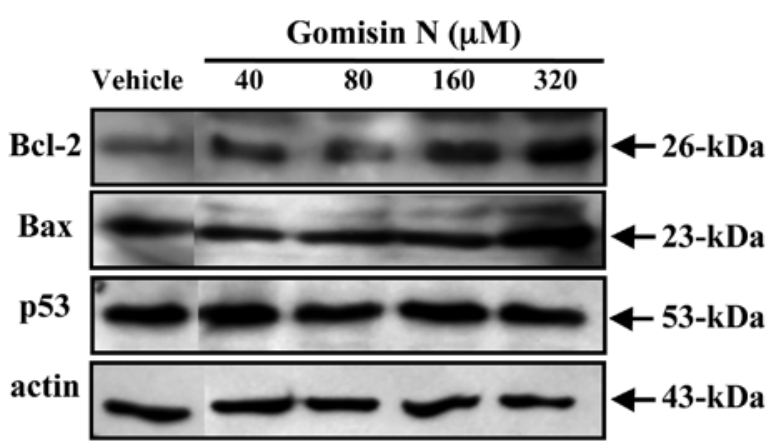

B.
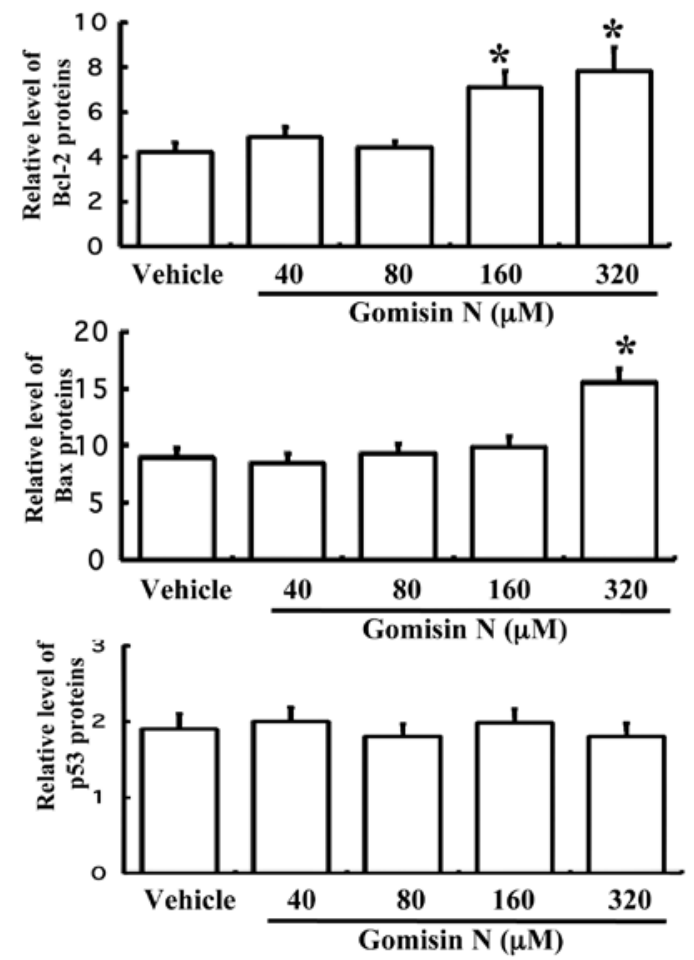

Figure 6. Effects of gomisin $\mathrm{N}$ on the apoptotic pathway and the expression levels of tumor suppressor gene. (A) Expression levels of Bcl-2, Bax and p53 proteins were analyzed using Western blot analysis. The membranes were incubated with antibodies for $\mathrm{Bcl}-2, \mathrm{Bax}, \mathrm{p} 53$ and $\beta$-actin proteins from the HepG2 cells treated with various concentrations of gomisin N. (B) Expression levels were quantified using an imaging densitometer. The sizes of each product are shown. Data represent the mean \pm SD of three experiments. "P $<0.05$ compared to the vehicle-treated group, set as the level of significance.

tion range. The expression level of Bax protein was markedly increased in only the $320 \mu \mathrm{M}$-treated group compared to the vehicle and to the other concentration groups. To examine whether the tumor suppressor gene in the HepG2 cells was affected by gomisin $\mathrm{N}$, the expression level of $\mathrm{p} 53$ protein was detected in the vehicle- and gomisin N-treated groups. The expression level of p53 protein remained unchanged in the four treatment groups and the vehicle (Fig. 6). These results suggest that gomisin $\mathrm{N}$ simultaneously induces an increase in the proteins associated with the anti-apoptotic and proapoptotic processes, but does not affect the expression level of the tumor suppressor protein p53. 


\section{Discussion}

Hepatocellular carcinoma is a primary malignancy of the hepatocytes, generally leading to death within 6-20 months. This disease is the fifth most common cancer in men and the eighth most common cancer in women worldwide (24). Cirrhosis of any etiology is known to be a major risk factor for hepatocellular carcinoma (25). To date, approximately $80 \%$ of patients with newly diagnosed hepatocellular carcinoma have pre-existing cirrhosis of the liver, caused mainly by excessive alcohol use, or by hepatitis C or B infection (26). Many therapeutic strategies are used for the medical treatment of hepatocellular carcinoma, including surgical resection and liver transplantation, although available treatment options depend on the characteristics of the tumor $(27,28)$. In this study, we investigated the anti-tumor functions of lignans newly isolated from Schisandra chinensis. Using a cell proliferation assay, our study demonstrated that gomisin $\mathrm{N}$ significantly induced cell death in hepatic carcinoma.

Lignans are the most common constituents of Schisandra chinensis. Major lignans in European seeds include deoxyschisandrin (0.07-1.09\%), gomisin N (0.24-1.49\%), schisandrin (0.75-1.86\%), wuweizisu C (0.01-0.34\%), and gomisin A (0.13-0.90\%) (29). In previous studies, several C18 dibenzocyclooctadiene lignans isolated from Schisandra chinensis have exhibited various therapeutic activities, including anti-cancer (30,31), anti-hepatocarcinogenetic (32,33), anti-hepatotoxic(34), anti-HIV (35), anti-oxidant (14,36), anti-inflammatory (31) and vascular relaxation (19) effects. Our research group previously discovered a hexane extract with cancer inhibitory abilities (14) in the fruits of Schisandra chinensis (Schisandraceae), which is indigenous to Korea, Japan and China. However, the literature is limited on the pharmacological mechanism of action of Schisandra chinensis.

The most active and abundant dibenzocyclooctadiene derivative isolated from Schisandra chinensis is schisandrin B (Sch B) (37). This derivative has been used for the treatment of viral and chemical hepatitis. Additionally, several studies have shown that Sch B protects against free radical-mediated hepatocellular damage and enhances hepatic glutathione antioxidant status in the mitochondria $(38,39)$. It has been reported that schisandrin B has enantiomers $[(+)$ Sch B and (-)Sch B] (40), which exhibit differential functions. (+)Sch B induces proliferation and apoptosis. Specifically, this compound was found to significantly enhance doxorubin-induced apoptosis in a human hepatic carcinoma cell line and in human breast cancer cells (41). In contrast, the structure of (-)Sch B is very similar to that of gomisin N. Pre-treatment with this compound significantly protected against hypoxia/reoxygenation-induced apoptosis in H9c2 cells (42). However, no studies have aimed to determine whether gomisin $\mathrm{N}$ affects cell proliferation and apoptosis. Gomisin $\mathrm{N}$ achieved the highest activity level among the four compounds screened in this study: gomisin N, schisandrin, schisandrin $\mathrm{C}$ and gomisin A. Specifically, gomisin N significantly inhibited cell proliferation by approximately $50 \%$ at high concentrations, though it did not contribute to the cell death process at low concentrations.

Apoptosis is characterized by various morphological features involving loss of plasma membrane asymmetry and attachment, fragmentation and condensation of the nucleus and formation of cytoplasm vesicles $(43,44)$. The loss of the plasma membrane is one of the earliest features noted in apoptosis, and is detected by Annexin V-conjugated FITC $(45,46)$. In our study, the above technique revealed that gomisin $\mathrm{N}$ markedly induced the loss of plasma membrane asymmetry at low concentrations. These effects remained unchanged at other concentration levels.

Apoptosis or programmed cell death plays a critical role in a variety of physiological processes during fetal development and in adult life. Defects in the apoptotic process lead to the development of many diseases involving progressive cell accumulation and, in most cases, cancer. Apoptosis involves many families of proteins. Of these proteins, Bcl-2 is one of the key molecules involved in induction as part of the anti-apoptotic process (47). Previous studies suggest that this protein is overexpressed in many solid tumors and contributes to chemotherapy resistance and radiation-induced apoptosis $(47,48)$. Unlike many other known human oncogenes, bcl-2 exerts its influence by enhancing cell survival rather than stimulating cell division (48). In this study, we investigated whether the expression level of the $\mathrm{Bcl}-2$ protein affects gomisin $\mathrm{N}$ treatment in hepatic carcinoma. As shown in Fig. 6, the expression level of $\mathrm{Bcl}-2$ protein remained at a consistent level at low concentrations, while high-concentration gomisin $\mathrm{N}$ treatment significantly increased $\mathrm{Bcl}-2$ protein expression levels.

The Bax protein, another member of the Bcl-2 family, inhibits the anti-apoptotic activity of Bcl-2. However, various reports suggest that bax acts as a classic tumor suppressor gene in vivo. Several human tumors had loss of function mutations for this protein, and knockout of the bax gene induced tumorigenesis in mice (49-51). When we examined the effects of gomisin $\mathrm{N}$ treatment on the expression level of the Bax protein using Western blot analysis, the expression level of Bax was significantly increased only in the $320 \mu \mathrm{M}$ group. These results suggest that the increase in Bax expression upon gomisin $\mathrm{N}$ treatment contributes to cell death by inhibiting anti-apoptotic activity.

Collectively, the results suggest that gomisin $\mathrm{N}$ is a novel candidate for the therapeutic treatment of hepatic carcinoma. However, intensive research is still required to define the role of this compound in inducing cell death in hepatocellular carcinomas for future clinical applications.

\section{Acknowledgements}

This study was supported by the Technology Development Program for Agriculture and Forestry (no. 106048031CG00) and by a Pusan National University Research Grant (2008).

\section{References}

1. Panossian A and Wikman G: Pharmacology of Schisandra chinensis Bail.: an overview of Russian research and uses in medicine. J Ethnopharmacol 118: 183-212, 2008.

2. Azzam HS, Goertz C, Fritts $M$ and Jonas WB: Natural products and chronic hepatitis C virus. Liver Int 27: 17-25, 2007.

3. Panossian AG: Effects of heavy physical exercise and adaptogens on nitric oxide content in human saliva. Phytomedicine 6: 17-26, 1999.

4. Chiu PY, Mak DH and Poon MK: In vivo antioxidant action of a lignan-enriched extract of Schisandra fruit and an anthraquinone-containing extract of Polygonum root in comparison with schisandrin B and emodin. Planta Med 68: 951-956, 2002. 
5. Ko KM: schisandrin B protects against tert-butylhydroperoxideinduced cerebral toxicity by enhancing glutathione antioxidant status in mouse brain. Mol Cell Biochem 238: 181-186, 2002.

6. Nakamura K, Yoshida M and Uchiwa H: Down-regulation of melanin synthesis by a biphenyl derivative and its mechanism. Pigment Cell Res 16: 494-500, 2003.

7. Yim TK and Ko KM: schisandrin B protects against myocardial ischemia-reperfusion injury by enhancing myocardial glutathione antioxidant status. Mol Cell Biochem 196: 151-156, 1999.

8. Baek MS, Kim JY and Myung SW: Metabolism of dimethyl-4,4'dimethoxy-5,6,5',6'-dimethylene dioxybiphenyl-2,2'-dicarboxylate (DDB) by human liver microsomes: characterization of metabolic pathways and of cytochrome P450 isoforms involved. Drug Metab Dispos 29: 381-388, 2001

9. Iwata H, Tezuka $\mathrm{Y}$ and Kadota S: Identification and characterization of potent CYP3A4 inhibitors in Schisandra fruit extract. Drug Metab Dispos 32: 1351-1358, 2004.

10. Chang HF, Lin YH, Chu CC, Wu SJ, Tsai YH and Chao JC: Protective effects of Ginkgo biloba, Panax ginseng, and Schisandra chinensis extract on liver injury in rats. Am J Chin Med 35: 995-1009, 2007.

11. Ko KM, Ip SP, Poon MK, Wu SS, Che CT, Ng KH and Kong YC: Effect of a lignan-enriched fructus schisandrae extract on hepatic glutathione status in rats: protection against carbon tetrachloride toxicity. Planta Med 61: 134-137, 1995.

12. Chen N, Chiu PY and Ko KM: schisandrin B enhances cerebral mitochondrial antioxidant status and structural integrity, and protects against cerebral ischemia/reperfusion injury in rats. Biol Pharm Bull 31: 1387-1391, 2008.

13. Kubo S, Ohkura Y, Mizoguchi Y, Matsui-Yuasa I, Otani S, Morisawa S, Kinoshita H, Takeda S, Aburada M and Hosoya E: Effect of gomisin A (TJN-101) on liver regeneration. Planta Med 58: 489-492, 1992

14. Choi YW, Takamatsu S, Khan SI, Srinivas PV, Ferreira D, Zhao J and Khan IA: Schisandrene, a dibenzocyclooctadiene lignan from Schisandra chinensis: structure-antioxidant activity relationships of dibenzocyclooctadiene lignans. J Nat Prod 69: 356-359, 2006.

15. Avula B, Dentali S and Khan IA: Simultaneous identification and quantification by liquid chromatography of benzethonium chloride, methyl paraben and triclosan in commercial products labeled as grapefruit seed extract. Pharmazie 62: 593-596, 2007.

16. Seo SM, Lee HJ, Park YK, Lee MK, Park JI and Paik KH: Lignans from the fruits of Schizandra chinensis and their inhibitory effects on dopamine content in PC12 cells. Nat Prod Sci 10: 104-108, 2004.

17. Ikeya Y, Taguchi H, Yosioka I and Kobayashi H: The constituents of Schizandra chinensis Baill. I. Isolation and structure determination of five new lignans, gomisin A, B, C, F and G, and the absolute structure of schizandrin. Chem Pharm Bull 27: 1383-1394, 1979.

18. Ikeya Y, Taguchi H, Yosioka I and Kobayashi H: The constituent of Schizandra chinensis Baill. III. The structures of four new lignans, gomisin $\mathrm{H}$ and its derivatives, angeloyl-, tigloyl- and benzoyl-gomisin H. Chem Pharm Bull 27: 1576-1582, 1979.

19. Park JY, Lee SJ, Yun MR, Seo KW, Bae SS, Park JW, Lee YJ, Shin WJ, Choi YW and Kim CD: gomisin A from Schisandra chinensis induces endothelium-dependent and direct relaxation in rat thoracic aorta. Planta Med 73: 1537-1542, 2007.

20. Andree HA, Reutelingsperger CP, Hauptmann R, Hemker HC, Hermens WT and Willems GM: Binding of vascular anticoagulant alpha (VAC alpha) to planar phospholipid bilayers. J Biol Chem 265: 4923-4928, 1990 .

21. Casciola-Rosen L, Rosen A, Petri M and Schlissel M: Surface blebs on apoptotic cells are sites of enhanced procoagulant activity: implications for coagulation events and antigenic spread in systemic lupus erythematosus. Proc Natl Acad Sci USA 93: 1624-1629, 1996

22. Tsujimoto Y: Role of Bcl-2 family proteins in apoptosis: apoptosomes or mitochondria? Genes Cells 3: 697-707, 1998.

23. Tsujimoto $\mathrm{Y}$ and Shimizu S: Bcl-2 family: life-or-death switch. FEBS Lett 466: 6-10, 2000.

24. Bosch FX, Ribes J, Díaz M and Cléries R: Primary liver cancer: worldwide incidence and trends. Gastroenterology 127: S5-S16, 2004.

25. Adami A, Hunter D and Trichopoulos D: Cancer of the liver and biliary tract. In: Textbook of Cancer Epidemiology. 2nd edition. Oxford University Press, Oxford, pp308-332, 2008.

26. El-Serag HB and Mason AC: Risk factors for the rising rates of primary liver cancer in the United States. Arch Intern Med 60: 3227-3230, 2000.
27. Thomas MB and Zhu AX: Hepatocellular carcinoma: the need for progress. J Clin Oncol 23: 2892-2899, 2005.

28. Bruix J and Sherman M: Management of hepatocellular carcinoma. Hepatology 42: 1208-1236, 2005.

29. He XG, Lian L-Z and Lin L-Z: Electrospray high performance liquid chromatography-mass spectrometry in phytochemical analysis of kava (Piper methysticum) extract. Plant Med 63: 70-74, 1997

30. Chen DF, Zhang SX, Kozuka M, Sun QZ, Feng J, Wang Q, Mukainaka T, Nobukuni Y, Tokuda H, Nishino H, Wang HK, Morris-Natschke SL and Lee KH: Interiotherins C and D, two new lignans from Kadsura interior and antitumor-promoting effects of related neolignans on Epstein-Barr virus activation. J Nat Prod 65: 1242-1245, 2002

31. Yasukawa K, Ikeya Y, Mitsuhashi H, Iwasaki M, Aburada M, Nakagawa S, Takeuchi $\mathrm{M}$ and Takido $\mathrm{M}$ : gomisin $\mathrm{A}$ inhibits tumor promotion by 12-O-tetradecanoylphorbol-13-acetate in two-stage carcinogenesis in mouse skin. Oncology 49: 68-71, 1992.

32. Ohtaki Y, Hida T, Hiramatsu K, Kanitani M, Ohshima T, Nomura M, Wakita H, Aburada M and Miyamoto KI: Deoxycholic acid as an endogenous risk factor for hepatocarcinogenesis and effects of gomisin A, a lignan component of Schizandra fruits. Anticancer Res 16: 751-755, 1996.

33. Nomura M, Nakachiyama M, Hida T, Ohtaki Y, Sudo K, Aizawa T, Aburada M and Miyamoto KI: gomisin A, a lignan component of Schizandora fruits, inhibits development of preneoplastic lesions in rat liver by 3'-methyl-4-dimethylamino-azobenzene. Cancer Lett 76: 11-18, 1994.

34. Wu MD, Huang RL, Kuo LM, Hung CC, Ong CW and Kuo YH: The anti-HBsAg (human type B hepatitis, surface antigen) and anti-HBeAg (human type B hepatitis, e antigen) C18 dibenzocyclooctadiene lignans from Kadsura matsudai and Schizandra arisanensis. Chem Pharm Bull 51: 1233-1236, 2003.

35. Chen DF, Zhang SX, Xie L, Xie JX, Chen K, Kashiwada Y, Zhou BN, Wang P, Cosentino LM and Lee KH: Anti-AIDS agents. XXVI. Structure-activity correlations of gomisin-G-related anti-HIV lignans from Kadsura interior and of related synthetic analogues. Bioorg Med Chem 5: 1715-1723, 1997.

36. Lu H and Liu GT: Anti-oxidant activity of dibenzocyclooctene lignans isolated from Schisandraceae. Planta Med 58: 311-313, 1992

37. Li XY: Bioactivity of neolignans from fructus Schizandrae. Mem Inst Oswaldo Cruz 86: 31-37, 1991.

38. Ip SP, Poon MK, Wu SS, Che CT, Ng KH, Kong YC and Ko KM: Effect of schisandrin B on hepatic glutathione antioxidant system in mice: protection against carbon tetrachloride toxicity. Planta Med 61: 398-401, 1995.

39. Ip SP and Ko KM: The crucial antioxidant action of schisandrin B in protecting against carbon tetrachloride hepatotoxicity in mice: a comparative study with butylated hydroxytoluene. Biochem Pharmacol 52: 1687-1693, 1996.

40. Chiu PY, Leung HY, Poon MK, Mak DH and Ko KM: (-) schisandrin $\mathrm{B}$ is more potent than its enantiomer in enhancing cellular glutathione and heat shock protein production as well as protecting against oxidant injury in $\mathrm{H} 9 \mathrm{c} 2$ cardiomyocytes. Mol Cell Biochem 289: 185-191, 2006.

41. Li L, Lu Q, Shen Y and Hu X: schisandrin B enhances doxorubicin-induced apoptosis of cancer cells but not normal cells. Biochem Pharmacol 71: 584-595, 2006.

42. Chiu PY, Luk KF, Leung HY, Ng KM and Ko KM: schisandrin $\mathrm{B}$ stereoisomers protect against hypoxia/reoxygenation-induced apoptosis and inhibit associated changes in $\mathrm{Ca}^{2+}$-induced mitochondrial permeability transition and mitochondrial membrane potential in H9c2 cardiomyocytes. Life Sci 82: 1092-1101, 2008.

43. Schwartz LM, Smitho SW, Jones MEE and Osborne BA: Do all programmed cell deaths occur via apoptosis? Proc Nati Acad Sci USA 90: 980-984, 1993.

44. Bursch W, Ellinger A, Gerner C, Fröhwein U and SchulteHermann R: Programmed cell death (PCD). Apoptosis, autophagic PCD, or others? Ann NY Acad Sci 926: 1-12, 2000.

45. Homburg CH, De Haas M, von dem Borne AE, Verhoeven AJ, Reutelingsperger CP and Roos D: Human neutrophils lose their surface Fc gamma RIII and acquire Annexin V binding sites during apoptosis in vitro. Blood 85: 532-540, 1995.

46. Koopman G, Reutelingsperger CP, Kuijten GA, Keehnen RM, Pals ST and van Oers MH: Annexin V for flow cytometric detection of phosphatidylserine expression on B cells undergoing apoptosis. Blood 84: 1415-1420, 1994. 
47. Apakama I, Robinson MC, Walter NM, Charlton RG, Royds JA, Fuller CE, Neal DE and Hamdy FC: Bcl-2 overexpression combined with p53 accumulation correlates with hormone refractory prostate cancer. Br J Urol 74: 1258-1262, 1996.

48. Joensuu H, Pylkkänen L and Toikkanen S: Bcl-2 protein expression and long-term survival in breast cancer. Am J Pathol 145: 1191-1198, 1994.

49. Baekelandt M,Holm R, Nesland JM, Tropé CG and Kristensen GB: Expression of apoptosis-related proteins is an independent determinant of patient prognosis in advanced ovarian cancer. J Clin Oncol 18: 3745-3747, 2000 .
50. Harima Y, Nagata K, Harima K, Oka A, Ostapenko VV, Shikata N, Ohnishi T and Tanaka Y: Bax and bcl-2 protein expression following radiation therapy versus radiation plus thermoradiotherapy in stage IIIB cervical carcinoma. Cancer 88: 132-138, 2000.

51. Ito T, Fujieda S, Tsuzuki H, Sunaga H, Fan G, Sugimoto C, Fukuda M and Saito H: Decreased expression of bax is correlated with poor prognosis in oral and oropharyngeal carcinoma. Cancer Lett 140: 81-91, 1999. 